\title{
Potency of Rosela Leaves (Hibiscus sabdariffa L.) as a Hepatoprotector to Histological Structure Damage of the Hepar of Male Mice (Mus musculus L.) Strain DDW that Proposed Natrium Nitrite $\left(\mathrm{NaNO}_{2}\right)$
}

\author{
Emita Sabri $^{1^{*}}$, Andri Sri Natalia Purba ${ }^{2}$, and Masitta Tanjung ${ }^{1}$ \\ ${ }^{1}$ Departement of Biology, Faculty Mathematics and Natural Science, Universitas Sumatera Utara, Jalan \\ Bioteknologi No. 1, Kampus USU, Padang Bulan, Medan 20155, Sumatera Utara, Indonesia. \\ ${ }^{2}$ Undergraduate student, Departement of Biology, Faculty Mathematics and Natural Science, Universitas \\ Sumatera Utara, Jalan Bioteknologi No. 1 Kampus USU, Padang Bulan, Medan 20155, Sumatera \\ Utara, Indonesia.
}

\begin{abstract}
The study of Rosela Leaf Extract As A Protective Agent Against The Damage Of Liver Tissue OfMale Mice Strain DDW that has been Induced By Sodium Nitrite was conducted. The experiment used Completely Randomized Design. The treatment given was three different dosages of rosella leaf extract, namely $14 \mathrm{mg} / \mathrm{ml}, 28 \mathrm{mg} / \mathrm{ml}$ and $42 \mathrm{mg}$ / $\mathrm{ml}$ and without any extract as a control. All mice have been induced by sodium nitrite for 18 days followed by healing process through injection of $0.3 \mathrm{ml}$ of rosella leaf extract at different concentration per day during 14 days. The result showed that he control, treatment of $14 \mathrm{mg} / \mathrm{ml}$ and $42 \mathrm{mg} / \mathrm{ml}$ affected the color change of liver tissue. However, the control increased liver tissue weight compared to all treatments. The damage levels of hepatocyte tissue treated by all different dosages of fresh rosella leaf extract decreased compared to the damage level of control. It could be concluded that fresh rosella leaf extract showed potential agent to protect liver mice from damage caused by sodium nitrite induction.
\end{abstract}

Keyword: Fresh extract, liver histology, $\mathrm{NaNO}_{2}$, rosela leaf

Received 8 June, 2020 | Revised 28 July, 2020 | Accepted 29 August, 2020

\section{Introduction}

The disease makes the medical world face various challenges. One of the emerging disease caused by the pattern of eating. The fast-paced demands of the safe have made some people prefer an instant-paced diet. Consumption of instant food can result in a negative impact on health due mostly instant foods contain preservatives, coloring, flavoring, high fat, high protein, sugar, and salt, but low in fiber. This diet triggers various diseases such as anemia, high blood pressure, diabetes mellitus, coronary heart disease, stroke, obesity and cancer [1].

${ }^{*}$ Corresponding author at: Jl. Bioteknologi No. 1 Kampus Univ. Sumatera Utara, Padang Bulan, Medan, Indonesia 
Food preservative such as sodium nitrite, commonly used in the process of canning meat. The use of sodium nitrite as a preservative is very dangerous for health [2]. Food fast -food potentially leave toxins in the body as fat, preservatives as well as sources of free radicals . Free radicals are toxic compounds that can affect the digestive system, especially the liver.

The liver functions to accommodate, transform, and excrete toxic substances. The liver is the center of metabolism in the body [3]. The liver can be protected by consuming medicinal plants such as roselle petals [4]. Rosella (Hibiscus sabdariffa L.) is a traditional medicinal plant that has a high vitamin $\mathrm{C}$ content among other medicinal plants. The high content of vitamin $\mathrm{C}$ in rosella can function as an antioxidant ingredient in the body. Vitamin $\mathrm{C}$ can inhibit compound effects of free radicals [5]. This study aims to determine the potential of fresh roselle leaves to function as a hepatoprotector against liver damage in mice.

\section{Materials and Methods}

\section{Preparation of Tools and Materials}

The tools used are balance scales, writing instruments, gavage needles, pins, surgical tub, dissecting set, sample cups, balm bottles, watch glasses, substance bottles, aluminum foil, pins, Winkler bottles, measuring cups, hotplates, digital cameras., microscope Primo Star Zeiss AxioCam Erc 5C , microtome, brush, basin, cover glass, object glass, beaker glass, counter, dropper, Erlenmeyer, pan, scissors, freezer, paraffin plate, cutter, thermometer, stirring rod, spatula, bunsen, jars, chumber, paperboard, $1 \mathrm{ml}$ spit, mortar, prep box, plasti k, rubber bands, napkins, filter paper, cotton, millimeter paper, label paper, holder, tissue, mancis, spritus, permanent markers, and experimental animal cages. The materials used were DDW strain male mice (Mus musculus L.), roselle leaves (Hibiscus sabdariffa L.), $\mathrm{NaNO}_{2}$, pellets (type $\mathrm{Pb551}$ ), husks, aquadest , 100\% alcohol, 96\%, 80\%, 70\% alcohol. , 60\%, 50\%, 40\%, 30\%, Bouin solution, $0.9 \% \mathrm{NaCl}$ solution, Hematoxylin and Eosin dyes, canada balsam, xylol, paraffin.

\section{Research design}

This study used a completely randomized design (CRD) with 4 treatments, namely 3 treatments of fresh rose la leaf extract (based on the weight of roselle leaves used, $14 \mathrm{mg}, 28 \mathrm{mg}$ and 42 $\mathrm{mg}$ ) and 1 solvent control (exposed to $\mathrm{NaNO}_{2}$ ). The number of replications is 6 tail, so the whole mice are used as many as 24 individuals.

\section{Provision of Research Animals}

This study used male mice (Mus musculus L.) DDW strain obtained from the Veterinary Investigation Center for Testing (BPPV) North Sumatera, Medan as much as 24 mice with weight $\pm 30 \mathrm{~g}$, and mice ready treated [6]. Each of the 6 mice was put in a plastic cage and 
given a husk pad. To keep the cage clean, change the husks twice a week [6]. The provision of food and drinking water, namely tap water, is done ad-libitum [7].

\section{Collection of Test Materials}

The test material used in this study was the fresh leaves of the roselle plant (Hibiscus sabdariffa L.) which were obtained and taken randomly from the plantation on Jalan Abdul Hakim, the alley of Kampung Susuk V, Medan.

\section{Preparation and Dosing of Extracts in Treatment}

The preparation of fresh roselle leaf extract is done by weighing rosella leaves in a variety of ways, namely $14 \mathrm{mg}, 28 \mathrm{mg}$, and $42 \mathrm{mg}$ (Directorate of Original Indonesian Medicine, 2010 modified by Susilowati [4]. Roselle leaves accordance weighing each dihalu scan using mortar, and than put in a glass beaker and add distilled water $1 \mathrm{ml}$ as a solvent, mixed, stirring and silenced [8]. The extract that has been obtained is given to the test animals orally using a gavage needle [7]. Volume administration of the extract as much as $0,3 \mathrm{ml} / \mathrm{mouse} /$ day [9].

\section{Pathological Treatment of $\mathrm{NaNO}_{2}$}

Treatment of pathological done by giving $\mathrm{NaNO}_{2}$ with the following conditions: average levels of NaNO 2 in oral in rats is $250 \mathrm{mg} / \mathrm{kg}$ of body weight. In this study, the body weight of the mice was $30 \mathrm{~g}$, so the levels of $\mathrm{NaNO}_{2}$ for each head were:

$\mathrm{NaNO}_{2}$ levels of mice $=\mathrm{NaNO}_{2}$ levels 2 mice

$$
\begin{aligned}
\mathrm{X} \mathrm{mg} / 30 \mathrm{~g} & =250 \mathrm{mg} / 1000 \mathrm{~g} \\
\mathrm{X} \mathrm{mg} & =(30 \mathrm{~g} \times 250 \mathrm{mg}) / 1000 \mathrm{~g} \\
& =7,5 \mathrm{mg}
\end{aligned}
$$

Effective pathological treatments include:

$$
\begin{aligned}
\operatorname{LD} 50 & =1 / 2 \times 7.5 \\
& =3.75 \mathrm{mg}
\end{aligned}
$$

So, the dose used for each head was $3.75 \mathrm{mg}$ dissolved in $1 \mathrm{ml}$ of aquadest. The volume of $\mathrm{NaNO}_{2}$ was given as much as $0.3 \mathrm{ml} /$ mouse/day [9].

\section{Treatment Sharing}

In this study, there were four treatments, each consisting of six replications, with the following divisions:

- Level I : Solvent control, exposed to $\mathrm{NaNO}_{2}$ for 18 days then followed by giving solvent (aquadest) for 14 days

- Level II : exposed to $\mathrm{NaNO}_{2}$ for 18 days and administration of rosella leaf extract as much as $14 \mathrm{mg} / \mathrm{ml} / \mathrm{mouse}$ for 14 days 
- Level III : exposed to $\mathrm{NaNO}_{2}$ for 18 days and administration of roselle leaf extract as much as $28 \mathrm{mg} / \mathrm{ml} / \mathrm{mouse}$ for 14 days

- Level IV : Exposure to $\mathrm{NaNO}_{2}$ for 18 days and administration of rosella leaf extract as much as $42 \mathrm{mg} / \mathrm{ml} /$ mouse 14 days..

\section{Liver Histotechnique with Paraffin Methods}

Preparation making is done by paraffin method as follows: fixation, washing, dehydration, purification, infiltration, planting, cutting, embedding, deparafination, dealcoholization, staining, packing, labeled and observed parenchymal degeneration, hydropic degeneration and necrosis under the microscope.

\section{Observation Parameters}

\section{Weight and Morphology of Liver}

Weighed liver and observed morphology of liver by means of male mice (Mus musculus L.) dislocated the neck and dissected, taken liver organs and observed. Liver weighing is performed using a digital scale, and is recorded as weighing. Morphological observations of liver are carried out by observing morphological images of liver with the observed target being the outer surface of the liver and the color of the liver. Normal assessments are characterized when the surface is flat and smooth and brownish-red, whereas abnormal if the surface is connective tissue, a small cyst, a bumpy surface or an abscess and indicates a discoloration [3].

\section{Histology of Liver}

Liver histological preparations were examined under mikr o the scope of light in the visual field yan $5 \mathrm{~g}$ different, with a magnification of 40 X 10 . Each visual field counted 20 cells randomly so that in that 1 preparation 100 liver cells were found. Then the mean weight of the hepatic histopathological change score was calculated in 5 fields of view of each mouse using the Manja Roenigk Histopathology Scoring model (Table 1) [10]. This type of damage observed liver necrosis, parenchymal degeneration, and hydropic degeneration. Then recorded and calculated the percentage of damage that occurred [11],[12].

Table 1. Assessment Score of Hepatocyte Damage Level

\begin{tabular}{lc}
\hline \multicolumn{1}{c}{ Damage Rate } & Score \\
\hline \multicolumn{1}{c}{ Normal } & 1 \\
Parenchymal degeneration & 2 \\
Hydropic degeneration & 3 \\
Necrosis & 4 \\
\hline (Criterion Spoiled Roenigk [13] was modified by Hapsari [14].
\end{tabular}




\section{Result and Discussion}

\section{Liver Weight of Mice}

The results of the observation of the liver weight of mice given fresh extract of roselle leaves with various doses (Figure 1).

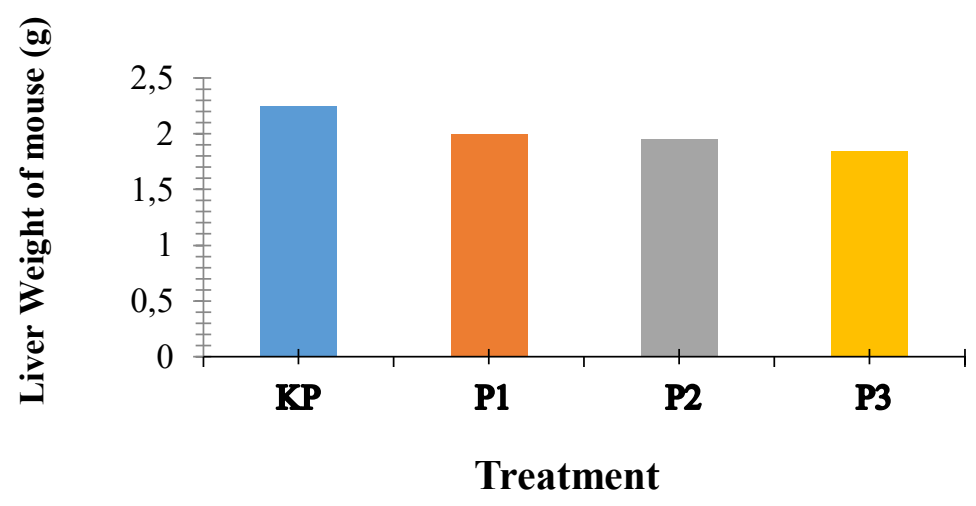

Figure 1 Liver Weight of Mice Exposed to $\mathrm{NaNO}_{2}$ and Recovered by Administration of Rosella Leaf Extract at Different Doses ; KP $\left(\mathrm{NaNO}_{2}+\right.$ aquadest $) ; \mathrm{P} 1\left(\mathrm{NaNO}_{2}+\right.$ rosella leaf extract $14 \mathrm{mg} /$ mouse); $\mathrm{P} 2\left(\mathrm{NaNO}_{2}+\right.$ roselle leaf extract $28 \mathrm{mg} /$ mouse $)$ and $\mathrm{P} 3\left(\mathrm{NaNO}_{2}+\right.$ roselle leaf extract $42 \mathrm{mg} /$ mouse).

Based on Figure 1, it can be seen that there is a decrease in the liver weight of mice at P1 (2.00 g), P2 (1.95 g) and P3 (1.84 g) when compared to KP (2.25 g). The results of statistical tests between KP and P1, P2 and P3 did not show a significant difference. It is suspected that this could occur because the roselle leaf extract with various doses might be able to have a positive impact on reducing the liver weight of mice in treatment. According to Almansour [15], the liver weight of normal adult mice ranges from 1.2-1.6 g. The decreasing of the liver weight in P1, P2 and P3 was seen to be closer to the normal liver weight of mice. Thus, it seems that giving roselle leaf extract can improve the reduction in liver weight of mice.

\section{Mice Liver Morphology}

The results of morphological observation of mice, shows P2 group keep in color and surface, able to said to the liver in a normal state $(100 \%$ of normal) . The treatment of $\mathrm{K}, \mathrm{P} 1$, and $\mathrm{P} 3$ experienced a change in color, namely that it looked pale and watery and the surface was mottled. P there is KP treatment can be seen (normal liver color $33.33 \%$ then $66.66 \%$ pale while on the normal liver surface $16.66 \%$ then abnormal $83.33 \%$ ), P 1 (normal liver color $33,33 \%$ then the pale $66.66 \%$ while on the normal liver surface $33.33 \%$ then the abnormal $66.66 \%$ ) and P3 (normal liver color $16.66 \%$ then the pale $83.33 \%$ while on the liver surface normal $16.66 \%$ then abnormal 83.33\%) (Table 2 and Figure 1) . 
Table 2 . Observation of Mice Liver Morphology

\begin{tabular}{cccc}
\hline \multirow{2}{*}{ Treatment } & \multirow{2}{*}{ Repeatation (n) } & \multicolumn{2}{c}{ Observation } \\
\cline { 3 - 4 } & 6 & Color (\%) & Surface (\%) \\
\hline KP & $33,33(\mathrm{~N})$ & $16,66(\mathrm{~N})$ \\
& 6 & $66,66(\mathrm{P})$ & $83,33(\mathrm{AN})$ \\
P1 & $33,33(\mathrm{~N})$ & $33,33(\mathrm{~N})$ \\
& & $66,66(\mathrm{P})$ & $66,66(\mathrm{AN})$ \\
P2 & 6 & $100(\mathrm{~N})$ & $100(\mathrm{~N})$ \\
P3 & 6 & $83,33(\mathrm{P})$ & $83,33(\mathrm{AN})$ \\
& & $16,66(\mathrm{~N})$ & $16,66(\mathrm{~N})$ \\
\hline Information: Color: Normal (N); Pale (P). Surface & $:$ Normal (N) ; Abnormal (A N ).
\end{tabular}

From Figure 2 it can be seen the difference in the color of the morphology of the liver, the treatment of KP (Figure 2a) color hepatic pale red and mottled surface when compared to the treatment P2 (Figure 2b) the color of liver maroon and smooth surface. With these conditions, it can be said that the color and surface of the KP treatment are abnormal while in P2 are normal. This is supported by the statement of Robins \& Kumar [3], that a normal liver has a flat and smooth surface and is brownish red, while an abnormal liver has a surface in the form of connective tissue, cysts and spots and changes color. Thus it can be seen that roselle leaf extract can improve the liver morphology of mice, including color and surface.

(a)

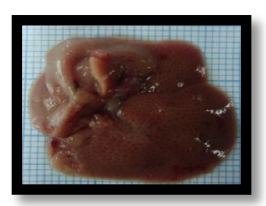

(b)

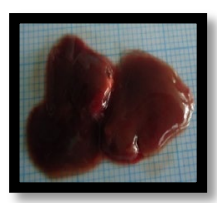

Figure 2 . Mice Liver Morphology . (a ) The liver morphology of mice on K P exposed to NaNO 2 for 14 days and then given aquadest for 18 days (pale red color and mottled surface); (b) The liver morphology of mice on P2 exposed to NaNO 2 for 14 days and then given fresh extract of rosella leaves for 18 days (red-brown color and smooth surface).

According Kristiana and Herti [16], the fresh leaves of roselle has vitamin C are high. According to Kumalaningsih [17], vitamin $\mathrm{C}$ is a source of antioxidants that have benefits for the body, such as helping to maintain cell health. $\mathrm{V}$ itamin $\mathrm{C}$ as an antioxidant function to bind oxygen so it does not support the oxidation reaction when the oxygen is not bound by the antioxidants would cause oxidative stress on the organs and this will cause hepatotoxicity.

\section{Overview of Histology of Mice Liver}

Histological liver of mice after got exposure $\mathrm{NaNO}_{2}$ then restored with a dose of leaf extract of roselle that some variations (Figure 3). In treatment P1 (220.89), P2 (183.94) and P3 (187.78) there was a decrease in damage when compared to KP (249.67). The results of statistical tests 
showed significant differences between P1, P2 and P3 when compared with KP. However, in $\mathrm{P} 2$, the reduction in the level of damage shows a very real difference when compared to KP. It can be seen from the 3 treatments of rosella leaf extract, although there was an improvement in hepatocyte damage when compared to KP, it was found that the most effective way to repair hepatocyte damage was at $\mathrm{P} 2$ at a dose of $28 \mathrm{mg} / \mathrm{ml}$ (Figure 3) .

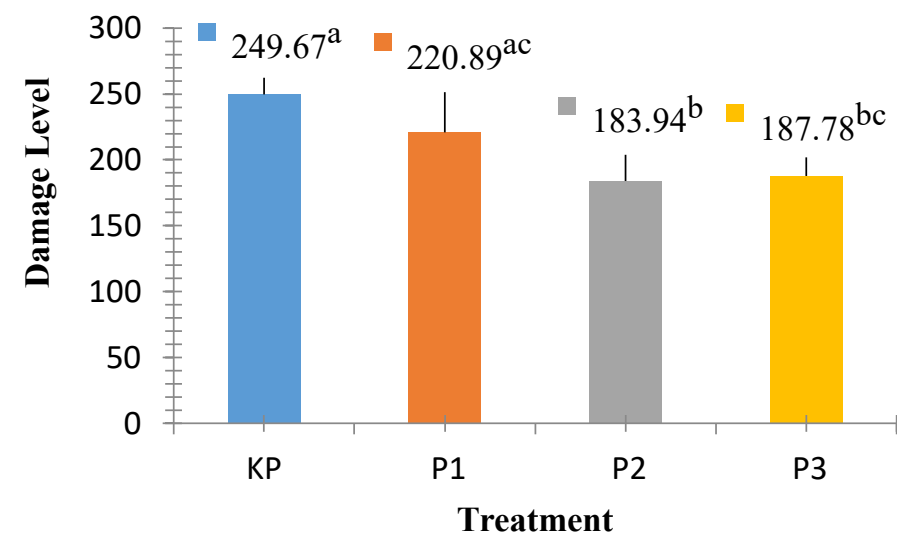

Figure 3. Damage to Hepatocytes Exposed to $\mathrm{NaNO}_{2}$ and Recovered by Administration of Rosella Leaf Extract at Different Doses ; KP $\left(\mathrm{NaNO}_{2}+\right.$ aquadest exposure); P1 $\left(\mathrm{NaNO}_{2}+\right.$ rosella leaf extract $14 \mathrm{mg} / \mathrm{mouse}) ; \mathrm{P} 2\left(\mathrm{NaNO}_{2}+\right.$ roselle leaf extract $\left.28 \mathrm{mg} / \mathrm{mouse}\right)$ and $\mathrm{P} 3$ $\left(\mathrm{NaNO}_{2}+\right.$ roselle leaf extract $\left.42 \mathrm{mg} / \mathrm{mouse}\right)$.

The lowest decrease in the level of hepatocyte damage was found in P2 treatment, this may occur because fresh roselle leaves have various kinds of content in them, among others; anthocyanin which is one type of flavonoid compound. As stated by Lil [18], that flavonoids are a group of the largest phenol compounds found in nature. These flavonoid compounds have antioxidant properties so that they can inhibit carcinogen activation. In addition it also roselle contains $\beta$ - carotene, according Hidajat [19] that, $\beta$ - carotene as a fat-soluble antioxidant that can keep the oxidant breakdown process in the cell wall composed of fat that can prevent cell swelling due to deposition of fat on hepatocytes.

According to Nugraha et al ., [20], compounds containing hydroxy or polyhydroxy groups, such as carotene in fruits, vegetables, and several other plants play an important role in hepatoprotective action. Then, beta-carotene also includes secondary antioxidants which are compounds that function to capture free radicals and prevent chain reactions so that greater damage does not occur .

The high content of vitamin $\mathrm{C}$ in rosella leaves a functions as an antioxidant, where antioxidants can capture elements of free radicals which can cause oxidative stress which can lead to various diseases or disorders in the liver. It was explained by Rini [21] that vitamin $\mathrm{C}$ as an antioxidant can help the liver work more effectively, so that the metabolic rate is faster. As a result, the healing process of disease is more optimal 


\section{Conclusion}

The administration of fresh extracts of rosella leaves (Hibiscus sabdariffa L.) can serve as a hepatoprotector against the damage to the histological structure of liver of male mouse the form of parenchymal degeneration damage, hydropic degeneration and necrosis exposure to Sodium Nitrite $\left(\mathrm{NaNO}_{2}\right)$.

\section{REFERENCES}

[1] American Diabetes Association. Cardiovascular Disease and Risk Management: Standards of Medical Care in Diabetes d 2020 Diabetes Care; 43 (Suppl. 1) : S111-S134 | 2020

[2] Winarno, F. G. Food Chemistry and Nutrition. Jakarta: PT. Gramedia Main Library. p. 159. 2004.

[3] Robbins, S. L. \& Kumar, V. Pathology Teaching Book 1. Surabaya: EGC Medical Book Publisher. p. 14-17. 1992.

[4] Susilowati, A.E. Effect of Giving Rosella Flower Extract (Hibiscus sabdariffa L.) Against Damage to Mencit Hepar Cells (Mus musculus) Due to Exposure to Paracetamol. [Thesis]. Surakarta: Faculty of Medicine Universitas Sebelas Maret. pp. 34-37. 2009.

[5] Kustyawati, Maria Erna \& Sulastri Ramli. 2008. Utilization of Rosella Ornamental Plant Results as Beverage Ingredients. Journal of Research. Lampung: University of Lampung. retrieved 3 May 2010.

[6] Smith, J. B., Mangkowidjoyo, S. Maintenance, Breeding and use of Experimental Animals in the Tropics. Jakarta: University of Indonesia Press. page 38, 43. 1988.

[7] Hrapkiewicz, K., \& Medina, L. Laboratory Animal. USA: Blackwell Publishing. Pages. 46, 51. 2007.

[8] Director General of POM. Pharmacopoeia Indonesia. 3rd Edition. Jakarta: Ministry of Health of the Republic of Indonesia. p. 9. 1995.

[9] Hutapea, A. Effects of Red Ginger Rhizome Extract (Zingiber offinale Var. Amarum) Against The Image of Ovary Histology Mencit (Mus musculus) Female Strain DDW. [Thesis]. Medan: Faculty of MIPA University of North Sumatra. p. 20. 2006.

[10] Desprinita, P. Effect of Administering 50\% Methanol Level Dose Per Oral On Hepar Cell Damage Rate In Wistar Mice. Articles of Scientific Writing. Semarang: Faculty of Medicine Diponegoro University. p. 8. 2010.

[11] Pawitra, I. \& Pearl, D. P. R. 2010. The Effect of Black Tea Administration (Camelia sinensis) on Histopathological Depiction of Hepar Mencit Balb/c. Articles of Scientific Writing. Semarang: Faculty of Medicine Diponegoro University. p. 12. 2010.

[12] Amalina, N. Acute Toxicity Test of Valerin Extract (Valeriana officinalis) Against Hepar Mencit Balb/C. Scientific Paper. Semarang: Faculty of Medicine Diponegoro University. p. 30-31. 2009.

[13] Roenigk, H.H., Auerbach, R., Maibach, H.I., \& Weinstein, G.D. Methotrexate In Psoriasis: Revised Guidelines. Journal Of The American Academy Of Dermatology. pages.19, 145. 1988. 
[14] Hapsari, R.A. The Effect of Long Administration of Methanol 50\% Per Oral On Hepar Cell Damage Rate In Wistar Rats. Articles of Scientific Works. Semarang: Faculty of Medicine Diponegoro University. p. 6. 2010.

[15] Almansour, M., Qais Jarrar, Abdelkader Battah and Bashir Jarrar. Morphometric Alterations Induced by the Toxicity of Variable Sizes of Silver Nanoparticles. Int. J. Morphol., 33(2):544-552, 2015.

[16] Kristiana, L \& Herti M. 2008. Benefits and Benefits of Rosela. Jakarta: PT. AgroMedia Library. p. 3-7, 25-30.

[17] Kumalaningsih, S. . Antioxidants, Sources \& Benefits. . http://antioxidantcentre.com/ index.php / Antioxidants Source Fabricated. html. Papaya Fruit (Carica papaya. L) Against CC14-induced Glomerular Epithelial Necrosis And Renal Tubules (Mus musculus). Malang: Faculty of Science and Technology Of Islamic State University. p. 18. 2007.

[18] Lil, H. 2008. The Effect of Papaya Fruit (Carica papaya. L) Against CCl4-induced Glomerular Epithelial Necrosis And Renal Tubules (Mus musculus). Malang: Faculty of Science and Technology Of Islamic State University. p. 18.

[19] Hidajat, Boerhat. 2005. Use of antioxidants in children. In: The Complete Manuscript of Continuing Education of Children's Health Sciences XXXV Capita Selekta Ilmu Kesehatan anak IV "Hot Topics in Pediatrics". Surabaya: FK UNAIR RSU Dr. Soetomo. p. $70-71$.

[20] Nugraha, U.S., N. S. Hadi \& S. U. Siwi. 2008. Hepatoprotative Effect of Mencit Male Strain of Swiss Induction CCl4. [Thesis]. East Java: Pharmacy Study Program of Jember University. Department of Biomedical. p. 1-2.

[21] Rini, M. D. The Effect of Giving The Black (Camelia sinensis) On The Histopathological Picture of Hepar Mencit BALB/C. Articles of Scientific Writing. Semarang: Bachelor of Medicine Education Program of Diponegoro University. p. 8. 2010. 